\title{
THE INFLUENCE OF CIVIL WORKS ON HERITAGE ARCHITECTURE, EL VERGEL, CUENCA - ECUADOR
}

\section{MARÍA G. BARSALLO ${ }^{1}$; FAUSTO A. CARDOSO ${ }^{2}$; EDISÓN R. SINCHI ${ }^{3}$; TATIANA E. RODAS ${ }^{4}$; MARÍA C. ACHIG-BALAREZO}

\author{
World Heritage City Project, Faculty of Architecture and Urbanism, \\ University of Cuenca, Cuenca, Ecuador, \\ 19abriela.barsallo@hotmail.com; ${ }^{2}$ faustocardosomartinez@gmail.com; ${ }^{3}$ edison.sinchit @ucuenca.edu.ec; \\ tyrodasa@hotmail.com; 5 cecilia_achig@
}

Keywords: Conservation, Civil Works, Earthen Architecture, Damages, Las Herrerias.

\begin{abstract}
In urban and rural areas of the Andean cities of Ecuador, construction based on earthen technologies has been an important alternative, which are carried out through ancestral customs, such as the minga, which benefit the cohesion of the community. Against this background, the World Heritage City Project of the University of Cuenca (Ecuador) has since the year 2011 undertaken interventions in heritage buildings inspired by the minga, so called Maintenance Campaigns, where the collective efforts of various actors (community, academy and organizations) are joined to recover buildings in highly vulnerable heritage neighborhoods, promoting preventive conservation, maintenance and monitoring of vernacular buildings.

The fourth campaign, which was carried out in 2018, took place in the Las Herrerias Street in the historical El Vergel neighborhood of Cuenca, a World Heritage City since 1999. The methodology applied in the previous campaigns was essentially maintained, gaining experience and innovating at every opportunity. As a special aspect, the Las Herrerias Campaign was characterized by the existence of buildings with structures that were already affected by civil works previously carried out, such as re-pavements, drinking water installations, various services, etc.

This research proposes to establish conservation strategies of vernacular heritage buildings and to mitigate the effects of poorly carried out civil works. The buildings intervened in the 2018 campaign are taken as reference, specifically those whose damages are the result of civil works. First, a review of bibliographic sources is undertaken to reveal historical data about the neighborhood and the civil works that have been carried out. The research continues with a diagnosis of the condition of the buildings before the Maintenance Campaign. Next, the daily maintenance records and the experience of the participants of the Campaign are investigated to identify and analyze those buildings affected by bad civil works practices and their impact on the damages of their structures. Subsequently, the condition of the buildings after the Campaign is evaluated.

Finally, strategies are proposed that must be considered for the interventions of vernacular heritage architecture, built with traditional earth and wood systems. Furthermore, civil works guidelines are defined for these types of interventions. Accordingly, the preservation for future generations of the wealth of material as well as immaterial heritage is encouraged.
\end{abstract}




\section{INTRODUCTION}

The Las Herrerias Street is located in El Vergel, a peripheral neighbourhood within the UNESCO area of the city of Cuenca (see figure 1), declared a World Heritage Site in 1999. This street is of high historical importance, since it used to be the main entrance to the preHispanic city of Tomebamba. Indeed, through this neighbourhood passed the so-called Qhapaq Nan, the Inca road system, which connected the two most important cities of the Inca Empire: Tomebamba and Cusco.

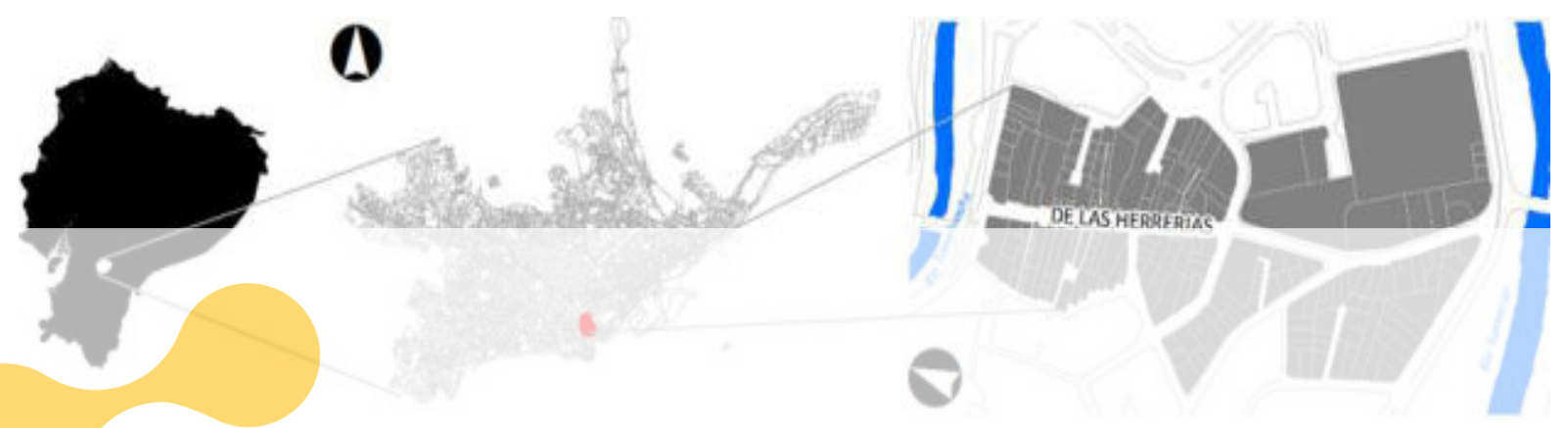

Figure 1: The location of the city of Cuenca, Ecuador, and the Las Herrerias Street. Source: Municipality of Cuenca
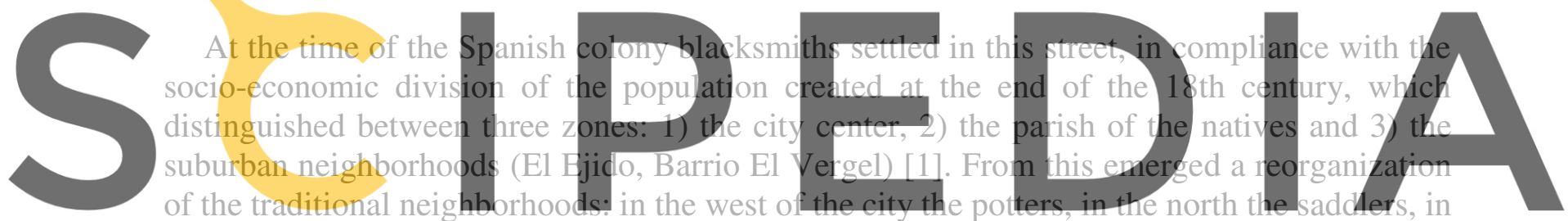

the south the bakers and in the southeast the blacksmiths [2].

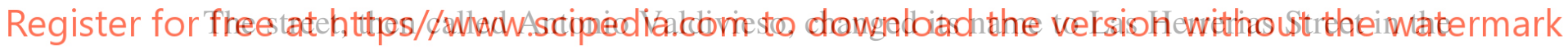
nineteen-seventies, in reference to the iron forging workshops that offered their services to the people passing through this street.

The architectural landscape is made up of vernacular buildings of adobe or bahareque, roofs of straw and clay and wooden structures covered with handmade tiles. These buildings formed the setting where the modest blacksmith workshops and small commercial shops operated in harmony with their residential use. The typologies of several of these buildings is made up of an interior or exterior portal and rooms derived from the need to work, exhibit, ventilate and live.

Being this a strategic entrance and exit of the city, the horse and mule riders left their animals attached to the portals, while going to the city center to sell and buy products. In this lapse of time the blacksmiths often repaired the horseshoes [3]. However, over time, the blacksmiths diversified into other products, such as locks, gates, nails, hinges, crosses, etc.

Furthermore, from the end of the 19th century, they started to make architectural products, such as handrails and windows, in tune with the new styles being used in the architecture in Cuenca. Today, several vernacular buildings are still present, but the economic activity of the blacksmith has declined in favor of restaurants and tourism. 


\section{THE LAS HERRERIAS STREET AND ITS INTERVENTIONS}

The high growth experienced by Cuenca since the second half of the 20th century brought with it the implementation of small to large civil works, which guaranteed better living conditions for its inhabitants [4]. This improvement of infrastructure and services caused a new challenge to the good conservation of buildings in the middle of an asynchronous reality. Although on one hand, it was important to improve the infrastructure and services with early actions, on the other, concerns about built heritage values only began to be explicit, discussed and applied half a century later. At the time of the execution of the major infrastructure works (re-pavements, drinking water installations, various services) the economic and heritage values of the buildings, from the planners 'and builders' perspective, were so low that without any objection the heights of the streets were drastically increased to give room to the new pavements required by the new guest of the historical city, the automobile. With its arrival, the streets were widened, leading to sidewalks and shoulders being pushed back and causing physical changes to many of the existing buildings. In addition, the elevation of the streets meant that the entrances to the buildings, which supposedly benefited from the new infrastructure, became exposed to flooding on rainy days with water entering the buildings from the street and the slow action of humidity through capillarity. Furthermore, several entrance doors were blocked. When getting wet, the earthen walls lost strength and collapsed one after another. In heritage terms, the price paid for the arrival of the automobile to the city was extremely high.

These interventions, which are normally assumed as the triumph of modernity over the

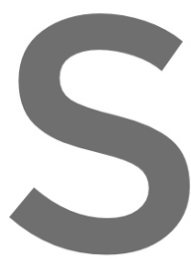
modest earthen architecture, historical centers of Ecuadoran $v$

One of the works that most Several portals were ren due to the widening neighborhood. Figure 2 shows how the level of the
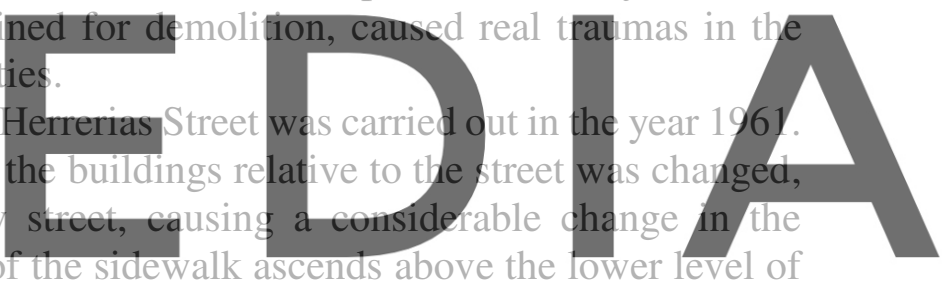
the building, causing the door to be cut off, water filtrations, danger of tripping over when

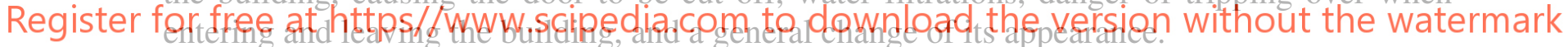

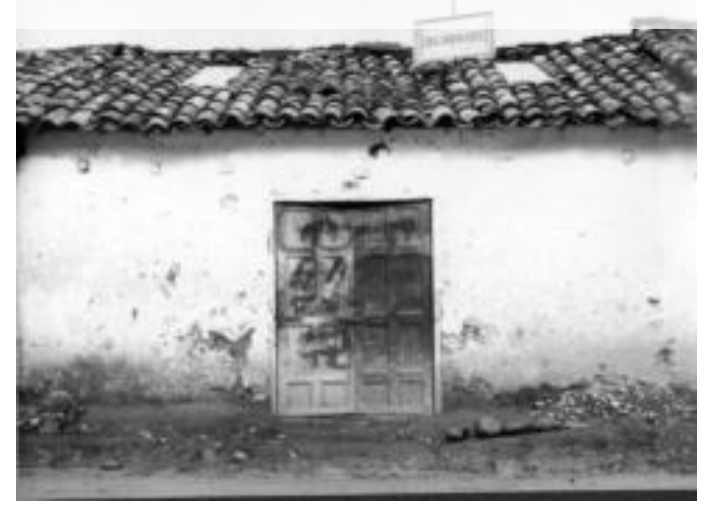

a)

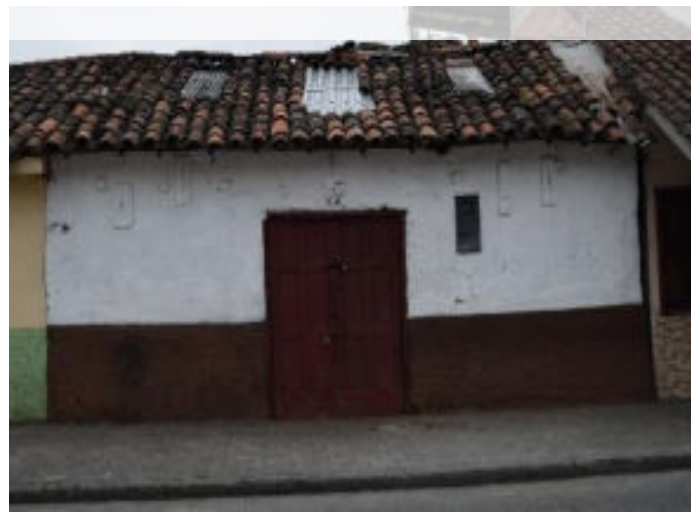

b)

Figure 2: a) Vernacular building in the Las Herrerias Street before the street was paved Source: a) Photographical archive of the Municipal Foundation "El Barranco" b) Vernacular building in the Las Herrerias Street after the street was paved Source: b) Photographical archive of the World City Heritage Projecct 
This is how public and private works have weighed on life in the cities. Due to the own dynamics of these processes the changes come about slowly, almost unnoticeable and with an aura of benefit to the neighborhood, causing them to be accepted without complaints nor critics by its own inhabitants. That is why the comparison of current with historical photos can be a very valuable tool to analyze and study the landscape.

The need for sidewalks also contributed to alter the environment due to the different materials used. At the beginning of the 20th century were introduced materials such as hexagonal cement bricks and unfinished concrete that are still being used today [5].

With the arrival of electrical and telephone services, and more recently cable TV and the internet, a new problem appeared for the historical centers: the destruction of the urban landscape. Enormous posts with swarms of devices and dozens of wires that enter and exit chaotically were placed in various parts of the neighborhood, occupying pedestrian space. Many of these wires are, in technical terms, dead wires, since they are no longer being used and have not been removed by the responsible companies. Although the need for public space illumination improves the safety in the neighborhood, it is necessary to carry out a detailed architectural landscape analysis to reduce the impact of this infrastructure on the landscape.

Additionally, with the consumerist emphasis of current societies, publicity also gained a position in the public space. Encouraged by the unfortunate idea of the bigger and more luminous the publicity the more successful the result, bit by bit appeared signs, advertisements and billboards that partially crown or cover many buildings, turning the urban historical landscape into a chaotic and disorganized scenery, in which the publicity is the true image of Finally, it should be noted that on seyeral occasions the Municipality of Cuenca tried to worl
in the Las Herrerías Street, socializing various projects, including paving the street and the
sidewalks (which included the burial of cables), which never materialized [0]. During the years
2017 and 2018, the University of Cuenca rnade an intervention proposal through a new
Maintenance Campaign for the heritage buildings of the traditional neighborhood El Vergel,

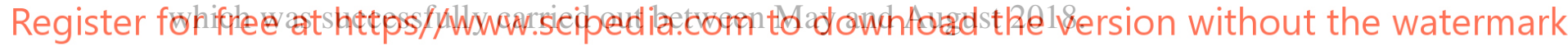

\section{MAINTENANCE CAMPAIGN OF THE HERITA GE BUILIDINGS OF THE}

\section{NEIGHBORHOOD EL VERGEL, LAS HERRERIAS STREET}

Since the year 2001, the World Heritage City Project $(\mathrm{CPM})^{1}$, with its focus on heritage conservation, has been applying Maintenance Campaigns of built heritage. These campaigns are aimed at the recovery of heritage buildings in vulnerable sectors through the collaboration of various social actors. These initiatives start off with an in-depth analysis by professors, students and researchers to identify the buildings to be intervened, determine their values, their damages and the activities to be developed. This work is carried out through participative workshops with the residents of the neighborhood and the support of various public and private entities, in order to forge commitments that are reflected in works, according to the expertise of each actor: the academy as leader and coordinator, organizations as strategic allies (institutions, foundations, associations and companies), the community, owners and neighbors

\footnotetext{
1 The vlirCPM project (Vlaamse Interuniversitaire Raad - City Preservation Management), in coordination with a consortium of Flemish Universities, lasted from the year 2007 until 2018. Its objective was to develop scientific foundations and provide education in order to improve the management of heritage sites in southern Ecuador, through the creation of management tools and the diffusion of knowledge. Currently the project is known as the CPM Project (City Preservation Management)
} 
in search of greater social involvement and cohesion of the neighborhood [7].

The first Campaign was applied in the year 2011 on 48 houses in the rural parish of Susudel and two years later a Campaign was carried out on the cemetery of Susudel. In the year 2014, a Campaign was carried out in an urban area in Cuenca, the neighborhood of San Roque, which is one of the neighborhoods of the city's UNESCO area [8]. Finally, in the year 2018, the Maintenance Campaign of the heritage buildings in the Las Herrerias Street of the El Vergel neighborhood was started. Based on this latest experience, during which 21 buildings were intervened, the influence of civil works on heritage architecture has been analyzed.

Without a doubt, the Maintenance Campaign was a challenge, since many of the buildings had considerably deteriorated roofs, columns and facades. The main problems consisted in rotten column bases, leading to a settling of the second floor and affecting the adobe walls as well as the roofs. Furthermore, the landscape was affected by the multitude of wires of different types, use and service [9]. Of a total of 226 damages, rot, stains and detachments account for more than $50 \%$, as shown in figure 3 .

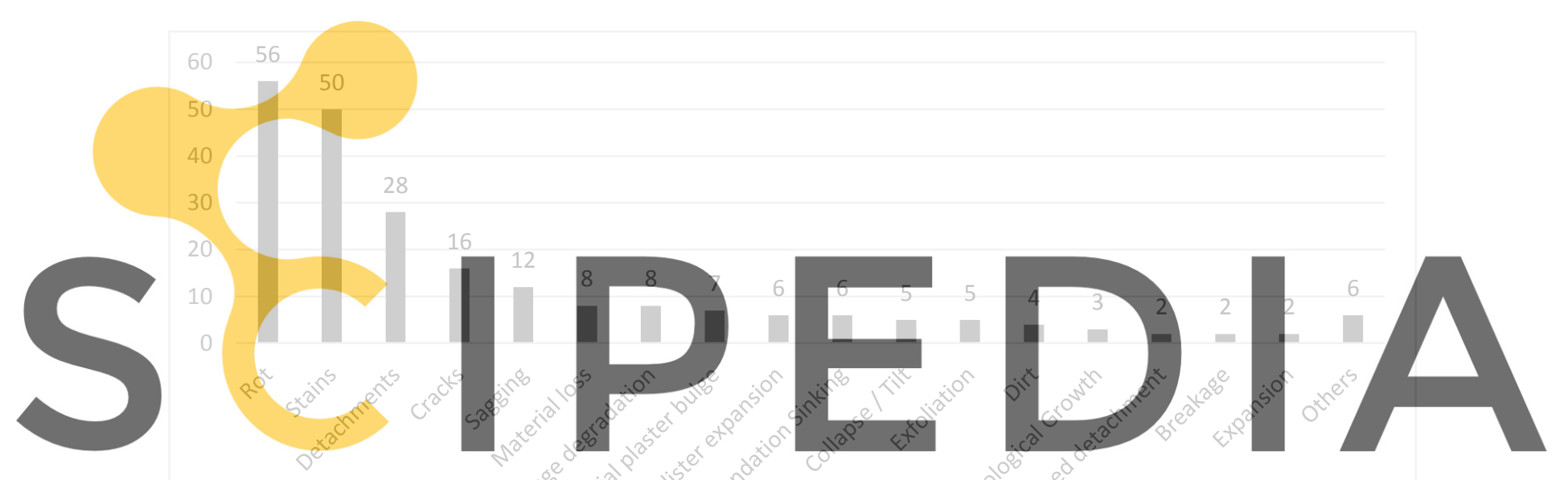

Register for free at https//www.scipedia.com to download the version without the watermark

Figure 3: Total number of identified damages before the Maintenance Campaign Source: World City Heritage Projecct, 2018

This investigation encountered several damages caused by civil works, such as poorly positioned posts, lights and wires as well as changes in the height of the street and sidewalk.

\subsection{Civil works as focus of the analysis for the recovery of heritage elements}

The effects caused by poorly carried out civil works in the Las Herrerias Street affect the most modest buildings. Especially the columns of the portals got damaged. During the Maintenance Campaign several stone elements, which served as column bases were found buried and as a consequence the wooden columns came into contact with the ground (due to a loss of height of the base) resulting in rot and loss of structural strength. Figure 4 highlights the buildings intervened during the Maintenance Campaign and those with portals. All have 
structural problems due to a weakening of their columns. Of the 6 buildings with portals, 5 had columns in direct contact with humidity or with buried bases and all of them were intervened and remedied.

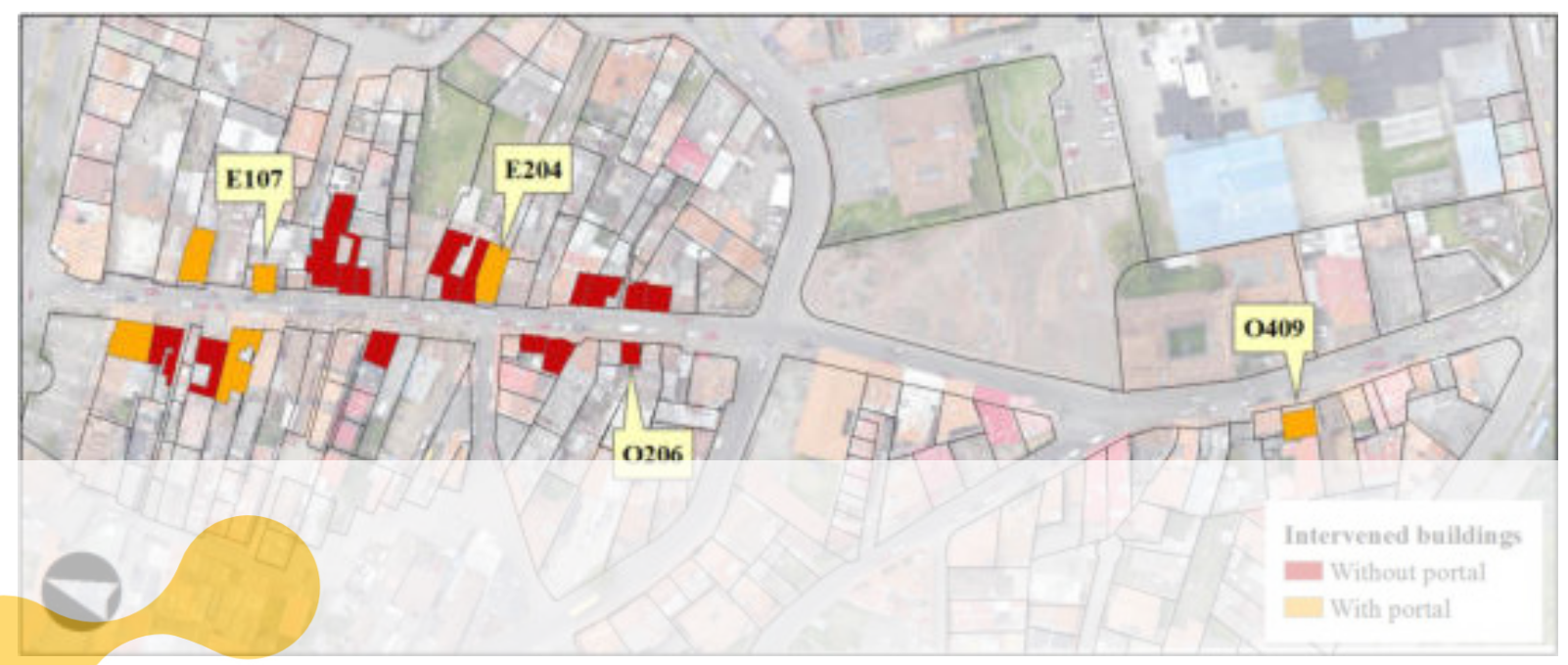

Figure 4: Buildings intervened during the Maintenance Campaign and buildings with portals Source: World City Heritage Projecct, 2018

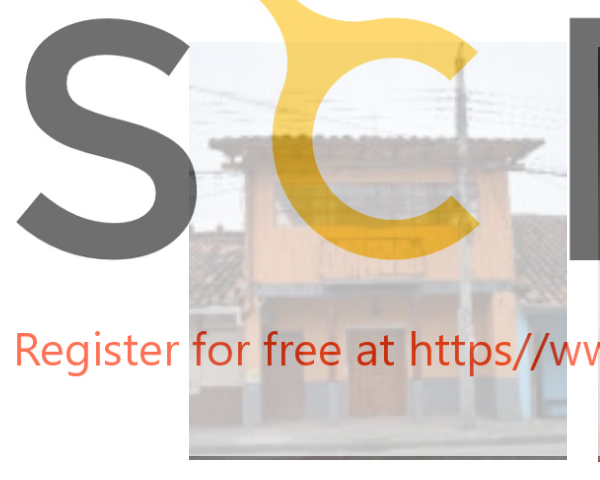

a

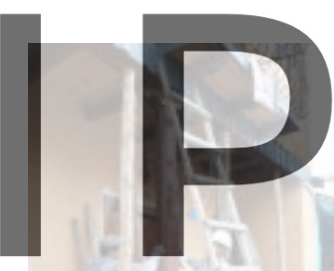

www.scipedia.com

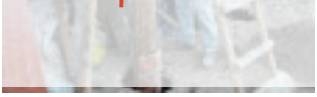

$\mathrm{b}$
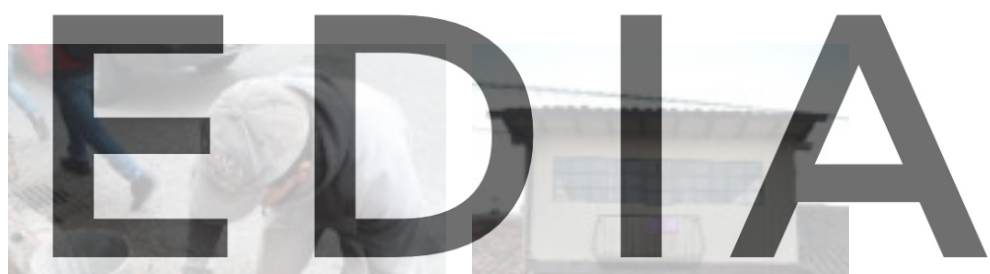

to download the version without the watermark d

Figure 5: León House (E204); main facade before the intervention; b) shoirng of the portal during the replacement of the bases; c) original unburied bases; d) columns after the intervention

Source: a, b,c,d) Photographical archive of the World City Heritage Projecct, 2018

A specific example is that of the León House (fig. 4, building E204), which had its stone bases buried several centimeters below the current ground level and replaced by cement coating as shown in photo a). Due to its contact with the ground, this caused an increase of moisture in the columns, leading to the bending of the beams that support the second floor. This type of protection not only affects the strength of the wooden column structure, but there is also a loss of value of the vernacular building due to not maintaining the traditional construction system. Figure 5 shows the situation before, during and after the Campaign. 


\subsection{Civil works as focus of the analysis for the relocation of urban elements}

Electrical installations: the building E204 (figure $5^{\mathrm{a}}$ ) is one of the few buildings that continues to have a vernacular constructive system of adobe on the ground floor and wood on the second floor. In this building the electrical installations were a danger due to the build-up of electrical wires close to its main facade. Similar situations were found in buildings E107 (figure 6a) and O206 (figure 6b), where posts with electrical wires were positioned through their wooden roofs, causing damages to their structures, ceilings, walls and plasters due to rainwater filtration.

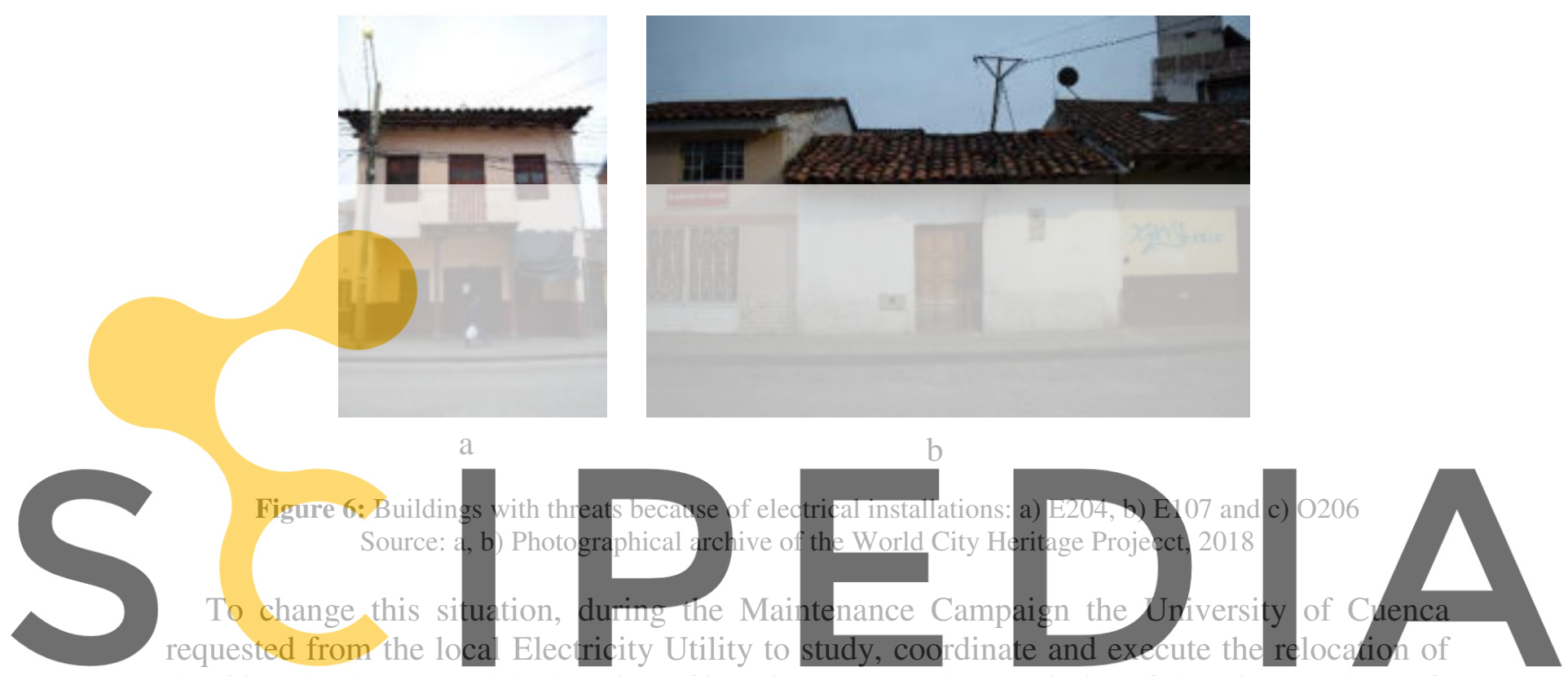

the 6 involved posts and the burying of its wires. Due to the proximity of the wires to the roofs

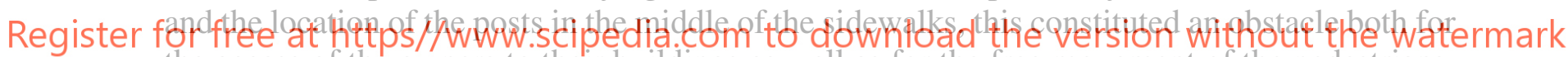

the access of the owners to their buildings as well as for the free movement of the pedestrians,

in addition to directly affecting a window and the aesthetics of the buildings. It is worth

mentioning that a Center for the Blind is located in this street, for which the public space needs to offer the necessary facilities. The local Electricity Utility carried out the complementary works of burying the wires within the Maintenance Campaign's intervention area of the street. This also allowed for a coordinated action between the Public Utilities of telecommunications, drinking water, sewage and sanitation to remove the so-called dead wires. In this way, an intervention of the urban space was realized that improved the quality of the services in the area and the image of the neighborhood.

\section{STRATEGIES FOR INTERVENTIONS IN VERNACULAR BUILDINGS CONSIDERING PREVIOUS CIVIL WORKS}

To develop proposals for the intervention of vernacular heritage buildings, a historical study should be considered. With the results of this study, the type of civil works that have been carried out in the area of interest are identified and it is thus possible to determine guidelines for a better intervention. Thanks to a detailed investigation during the Las Herrerias Maintenance Campaign it was discovered that previously the street was located at a lower level 
and that led to the recovery of the stone column bases, which were buried in the sidewalks.

The civil works carried out in the city of Cuenca since the first decades of the 20th century were essential to meet the needs for public health, security and to improve the inhabitants' quality of life. However, these should have been carried out in a properly planned manner, such that they would not have negatively affected the structures of the heritage buildings. In recent years, one can still see how civil works continue to cause damage to heritage buildings. In the year 2016, due to the widening of the Ordoñez Lasso Avenue, in the west of Cuenca, 11 buildings were totally or partially demolished [10]. Some of these were left with rooms of only three walls and out in the open, causing their accelerated deterioration.

The infrastructure civil works in heritage areas is delicate and should involve the presence of a heritage and landscape expert. Electrical, drinking water, sewerage, internet and other infrastructure should preferably be buried. This avoids minor as well as mayor problems, such as those in the Las Herrerias Street, where posts perforated the roof eaves of the heritage buildings and multitudes of wires were left hanging.

Furthermore, the intervention studies of vernacular heritage buildings in historical neighborhoods should be carried out together with the residents of the neighborhood through open, participative and inclusive processes. The suggestion by the Municipality of Cuenca during the first decade of the 20th century to make the Las Herrerias Street and sidewalk at the same level, without sidewalk borders, was rejected by the neighbors, who noted the risk of rainwater entering the buildings, due to the level of the sidewalk being lower than the entrance

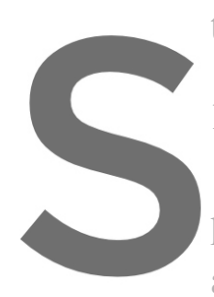
to their buildings.

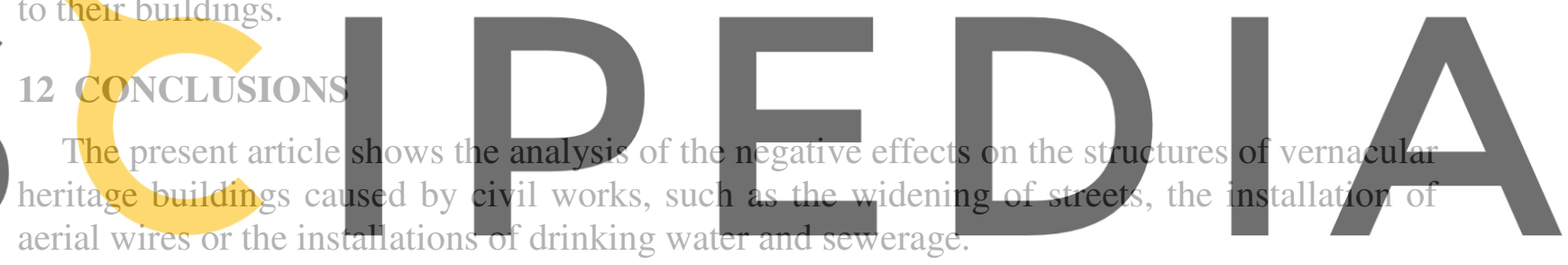

In the Las Herrerias Maintenance Campaign various problems related to civil works were

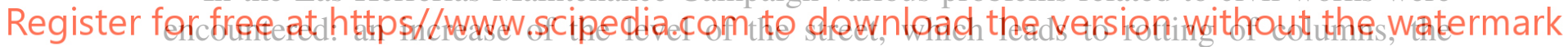
blocking of doors and the entrance of rainwater into the buildings; the location of electricity posts, which form an obstacle for pedestrians and cause the filtration of rainwater into the buildings; the multitude of aerial cables and the proximity of these to the buildings, which damage the aesthetics of the neighborhood and increase the risk of fires. During the Maintenance Campaign, many of these problems were addressed and solved.

A special case in the Las Herrerias Maintenance Campaign is the wooden columns that had their bases buried in the ground when the level of the street was increased, and consequently gradually lost their strength due to humidity. This in turn negatively affected other structural elements, such as beams, roofs and walls. Furthermore, during the intervention of heritage buildings the traditional construction techniques, such as the stone column bases, which function as a separation element between the wooden column and the ground, should be maintained, since these traditional construction techniques are part of the heritage values of buildings and have allowed for the heritage buildings to maintain their importance through time.

It is essential to work together with the neighborhood, to know their opinions as residents, in order to, together with the civil works, improve their quality of life, avoiding problems they had to face in the past, such as the entrance of rainwater into their buildings due to the higher 
level of the street.

Without a doubt, the motivations to improve the living conditions of a city go hand in hand with the carrying out of civil works, such as: paving streets to eliminate sand dust and adequate public illumination to improve security. However, they should be carefully planned without affecting the existing heritage buildings and must take into account the different constructive elements and values of the vernacular buildings. This prevents the loss of architectural heritage values, creating a harmony between the civil works, the traditional vernacular architecture and its surroundings.

\section{REFERENCES}

[1] Castro, J.D., Muñoz, C., Quizhpe, M. A., Pogo, M. \& Tenén, T. Expediente: “Campaña de mantenimiento de las edificaciones patrimoniales para el barrio El Vergel, calle de las Herrerías". Noveno ciclo de la opción de Conservación de Monumentos y Sitios. Facultad de Arquitectura y Urbanismo de la Universidad de Cuenca. (2018)

[2] González, I. Cuenca: barrios de tierra y de fuego: desintegración de los barrios artesanales, Cuenca, Ecuador: Fundación Paul Rivet. (1991),

[3] Estrella, P. Cuenca en el siglo XIX: la casa- quinta de Chaguarchimbana, (Serie Arquitectura y Urbanismo en el Ecuador No. 1) Cuenca, Ecuador: Fundación Paul Rivet. (1992).

[4] Carpio Vintimilla, J.; "Cuenca: Su geografía urbana"; López Monsalve Editores; Cuenca Ecuador; (1979) pág. 3
Albornoz, B.; Cuenca;
Fundación Municipal "
Albornoz, B.; Cuenca,
Fundación Municipal "

[7] Achig-Balarezo,

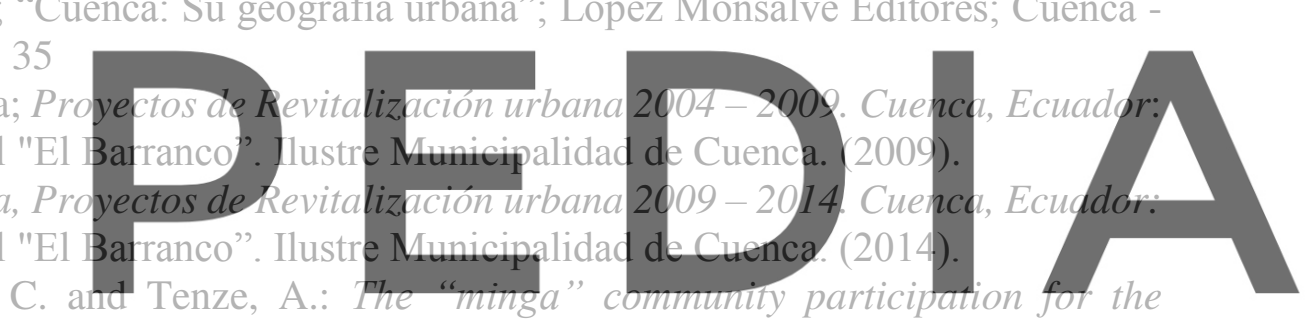
maintenance of vernacular heritage buildings in the historical center of Cuenca, Ecuador,

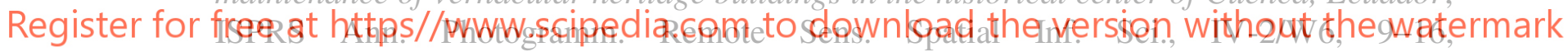
https://doi.org/10.5194/isprs-annals-IV-2-W6-9-2019, (2019).

[8] Cardoso, F., Achig-Balarezo, M., Vázquez, L., Barsalio, G.; La Conservación Preventiva en Tierra en el sur del Ecuador. En Terra Lyon 2016, Lyon - France, )2016)., pp. 136

[9] Castro, J.D., Muñoz, C., Quizhpe, M. A., Pogo, M. \& Tenén, T. Expediente: "Campaña de mantenimiento de las edificaciones patrimoniales para el barrio El Vergel, calle de las Herrerías". Noveno ciclo de la opción de Conservación de Monumentos y Sitios. Facultad de Arquitectura y Urbanismo de la Universidad de Cuenca. (2018)

[10] Tomado del diario El Tiempo. Noticia publicada el 15 de noviembre de 2016. Descargado de: https://www.eltiempo.com.ec/noticias/cuenca/2/casas-de-la-av-ordonez-lasso-serandemolidas. 